\title{
AOR
}

Selected Papers of \#AolR2021:

The 22nd Annual Conference of the Association of Internet Researchers Virtual Event / 13-16 Oct 2021

\section{VIRTUALLY AMISH: PRESERVING COMMUNITY AT THE INTERNET'S MARGINS}

\author{
Lindsay Ems \\ Butler University
}

My forthcoming book (MIT Press), Virtually Amish, is an ethnographic study of the adoption, and use of digital communication technologies among members of Old Order Amish communities. This paper explores a section of the book focusing on Amish strategies for internet management. Today it is increasingly common for the Amish to adopt computers, the internet and mobile devices in calculated ways to remain competitive in business. The concept internet management is a system of decisions and actions that can be managed by a business owner to mediate their relationship with anonymous others through the internet. Because many Amish already outsource tasks related to their businesses like transportation, accounting and printing, the system already fits within current business practices. Strategies like these are in place to protect Amish communities from the negative impacts of connectivity. Data was collected via semi-structured interviews with thought-leaders (business and religious leaders) in Indiana Amish settlements.

Amish communities today are in the process of determining how to navigate the social forces that have come along with, what theorists like Shoshana Zuboff (2019) call, hightech capitalism. Amish people describe internet technologies as both functional tools and symbols of engagement with, and resistance to the external social world. If not properly mitigated, they feel this external world has the potential to erode their culture and religion from the outside in. This research shows that decisions about technologies are productive sites of struggle that enable the Amish to create and sustain a dynamic social and cultural sanctuary where their way of life can thrive while resisting the disempowering aspects of the world around them.

This research illustrates how members of Old Order Amish communities calibrate their use of communication technologies strategically in an effort to resist macro-level social forces that work to fragment people in their communities from nature, religion and each other. Many social theorists have also noted what the Amish seek to resist in the world 
around them. Namely, digital technology works to amplify certain negative impacts of capitalism on people's lives. For example, they alter and accelerate our experience of time (Virilio 2006) and place by fragmenting people from nature (Brende 2005, Borgmann 1984) and each other (Putnam 2000, Sennett 1996, Zuboff 2019). Digital technologies contribute to the alienation of workers by making their labor invisible (DyerWitheford 1999, Gray \& Suri 2019) and under-paid (Duffy 2017, Geissler 2014). The everyday lived experience of people working in a capitalist economy that is increasingly fueled by high technology is characterized by increased stress and anxiety (Rosen et al. 2012), increased feelings of loneliness (DiJulio et al. 2018) and an inability to fashion a long-term narrative of one's life (Sennett 1996). Importantly, analysts have noted that these negative experiences result from an inability to opt-out of participation in a larger social and economic structure where power is intentionally, asymmetrically distributed and the most oppressed and marginalized people in society more acutely experience all of these negative impacts (Castells 2009, Eubanks 2012, 2019, Noble 2018, O'Neil 2016, Tufekci 2017, Yueng 2019). The few individuals who have the most power in society own and program the infrastructures that undergird the high-tech economy by collecting user data and using it to further strengthen their power and control.

While the various theoretical critiques of capitalism abound, there are few modern examples of everyday people who have found a sweet spot in which their participation in the economy allows them to acquire resources that can be used to fulfill their social, cultural and political desires regardless of whether or not they align with the system's. Remarkably, members of Amish communities do just this. They participate in the global economy while maintaining cultural, spiritual and ideological autonomy in defiance of what Shoshana Zuboff calls, "Big Other." Big Other refers to an instrumentarian super power reigning over today's high-tech society that "reduces human experience to measurable observable behavior while remaining steadfastly indifferent to the meaning of that experience" (376-77). In this new regime, "Big Other poaches our behavior for surplus and leaves behind all the meaning lodged in our bodies, our brains, and our beating hearts" (377). The lived experience under Big Other is a new kind of automaticity, a digital logic "that thrives within things and bodies, transforming volition into reinforcement and action into conditioned response" (Zuboff 2019, 379). This form of power is designed to reduce uncertainty in society and produce knowledge and profits for surveillance capitalists.

That the Amish actively make decisions about technology that rest upon their unique moral, spiritual and faith-based values puts them precisely outside Big Other's reign of power. They do not acquiesce to surveillance by this new authority and do not consent to the re-writing of the religious, faith-based texts and identities that guide their behavior. As such, their decisions about technology adoption and use provide an example of resistance to the powerful assault on the human capacity for authoring one's morals and will that we all face today. 


\section{References}

Brende, Eric. (2005) Better Off: Flipping the Switch on Technology. New York: Harper Perennial.

Borgmann, A. (1984) Technology and the Character of Contemporary Life. Chicago: University of Chicago Press.

Castells, M. (2009). Communication Power. Oxford: Oxford University Press.

DiJulio B, Hamel L, Munana C, Brodie M. Loneliness and Social Isolation in the United States, the United Kingdom, and Japan: An International Survey. Kaiser Family Foundation; 2018. Accessed May 28, 2020. kff.org/other/report/loneliness-andsocial-isolation-in-the-united-states-the-united-kingdom-and-japan-aninternational-survey/

Duffy, B. E. (2017). (Not) getting paid to do what you love: Gender, social media, and aspirational work. New Haven, Connecticut: Yale University Press.

Dyer-Witheford, N. (1999). Cyber-Marx: Cycles and circuits of struggle in hightechnology capitalism. Urbana, Illinois: University of Illinois Press.

Eubanks, V. (2012). Digital dead end: Fighting for social justice in the information age. Cambridge, Mass: MIT Press.

Eubanks, V. (2019). Automating inequality: How high-tech tools profile, police, and punish the poor. New York Picador: St. Martin's Press

Geissler, H. (2014). Seasonal Associate. Leipzig: Spector Books.

Gray, M. and Suri, S. (2019) Ghost Work: How to Stop Silicon Valley from Building a New Global Underclass. New York: Houghton Mifflin Harcourt.

Noble, S. U. (2018). Algorithms of oppression: data discrimination in the age of Google. New York: NYU Press.

O'Neil, C. (2016). Weapons of Math Destruction. New York: Broadway Books.

Putnam, R. D. (2000). Bowling alone: The collapse and revival of American community. London: Simon \& Schuster.

Rosen, L. D., Whaling, K., Rab, S., Carrier, L. M. and Cheever, N. A. (2012) "Is Facebook creating "iDisorders"? The link between clinical symptoms of psychiatric disorders and technology use, attitudes and anxiety." Computers in Human Behavior, 29(3): 1243-1254.

Sennett, R. (1998). The corrosion of character: The personal consequences of work in the new capitalism. New York: W.W. Norton. 
Tufekci, Z. (2017, October) We're building a dystopia just to make people click on ads. Retrieved from https://www.ted.com/talks/zeynep tufekci we re building a dystopia just to m ake people click on ads?language $=$ en

Virilio, P. (2006). Speed and politics: An essay on dromology. Los Angeles: Semiotext(e).

Yeung, P. (April 2019) The grim reality of life under Gangs Matrix, London's controversial predictive policing tool. Wired. Accessed May $28^{\text {th }}, 2020$. https://www.wired.co.uk/article/gangs-matrix-violence-london-predictive-policing

Zuboff, S. (2020). The age of surveillance capitalism: The fight for a human future at the new frontier of power. 